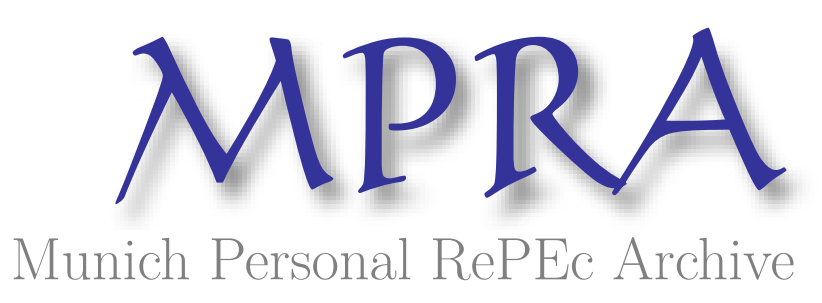

\title{
Conceptualizing Service Export Price Optimization
}

Sinha, Avik

Indian Institute of Management Indore

2015

Online at https://mpra.ub.uni-muenchen.de/102264/

MPRA Paper No. 102264, posted 06 Aug 2020 06:36 UTC 


\title{
CONCEPTUALIZING SERVICE EXPORT PRICE OPTIMIZATION
}

\author{
Avik Sinha \\ Fellow Programme in Management, Economics \\ Indian Institute of Management Indore \\ Indore \\ India
}

\section{Abstract:}

- Purpose: In this paper, it has been tried to formulate a conceptual model for service-oriented export pricing by looking at both demand and supply side considerations by taking export price as a function of domestic price of service.

- Design/methodology/approach: Continuous time optimization technique has been adopted for maximization of the profit earned by firm in the domestic and foreign market for both demand and supply side scenarios. Dynamic simulations have also been carried out in order to find out the sensitivity of parameters in diverse scenarios.

- Findings: We have received different results for demand and supply sides for export price optimization. Various pricing objectives have been aligned to the price determining parameters in accordance with the dynamic simulation performances.

- Research limitations/implications (if applicable): Continuous time optimization served our purpose, as we did not consider sustainability of the same decision over a longer period. However, discrete time optimization can be taken up, if effect of a series of decisions is scrutinized. More flexibility can be incorporated in the model, if a range of domestic price is considered over the singular domestic price.

- Practical implications (if applicable): This paper is significant for those firms, which are willing to extend their operations beyond the national boundary. The models derived here can give them an idea about how to price service in foreign market.

- Originality/value: Aligning pricing objectives with export price determining parameters by considering demand and supply side perspectives in a continuous time optimization model is a new contribution in the existing literature.

Keywords: export price, continuous time optimization, inflation, price elasticity of demand, willingness to pay, production function 


\section{Introduction}

Profit creation and maximization are main objectives for any firm. Across all marketing mix, price is the only able one to generate revenue and add value to aforementioned objective. Therefore, it is important for the firms to optimize their pricing decision in order to act globally. This pricing decision is same across the firms working in product domain or service domain. For this paper, we have considered the firms, which are working in the service domain. While setting up any service oriented pricing decision, it is needed to consider economic factors for domestic as well as foreign market, as the operation of firms are not confined by boundaries of nation. Policy level decisions by firm alter with the changes in global economic scenario (Kortge, Okonkwo, Burley, \& Kortge 1994). At any point of time, firm will be having four pricing alternatives: market skimming, price penetration, market holding and premium pricing (Zaribaf, 2008). However, firm needs to alter between these four pricing strategies, depending on changes in economic factors in global market. Hence monitoring of market dynamism factors is required at a continuous basis. Considering the existing body of literature in the domain of marketing, it has been observed that alteration of pricing decisions possibly not covered the demand and supply side considerations of the market, where lies the focus of this paper. Here, we have considered export price of a service as a function of domestic market price, and by optimization of the latter, considering both of the aforementioned scenarios, a model has been developed, where it has been tried to encompass the umbrella of objective factors in the process of service pricing decision. Making use of a hypothetical example for academic purpose and the example of Indian IT industry for industrial purpose, the model has been tested. Through this model, we have demonstrated how dynamically various objective economic factors can influence the pricing decision for a firm, which is intending to price its service for international market. Bringing forth the dynamism aspects in the model is a contribution in the literature of pricing for services in international market.

The paper is divided in four parts. In the literature review section, existing literature in this domain has been discussed and the research gap has been identified. Based on the parameters found and research gap established in literature review section, a pricing model has been formulated in the next section. Once the model has been developed, it has been tested for academic and industrial purpose in the discussion section. Finally, by putting forward the limitations and further scope of study, the paper has been concluded.

\section{Literature Review}

In formulating any service oriented pricing decision in global market, firm needs to consider those factors, which affect pricing decisions directly or indirectly (Sundaram \& Black, 1992; Phatak, 1998). These factors have been addressed in this paper by looking at the problem from demand (Sawyer, 1981; Montgomery \& Rossi, 1999) and supply (Noble \& Gruca, 1999) side perspective. Cost has been a considerable direct factor in pricing decision considering demand side of the story (Joskow, 1973; Kalish, 1983; Domowitz, Hubbard \& Petersen, 1986; 
Monroe, 1990). As cost of service development and design escalates, profitability of firm declines. Hence, to remain competitive in the market, it is needed for firms to reduce the cost of development (Spence, 1984). While talking about demand side perspective, nature of market also comes into picture. Nature of any global market can be characterized by willingness of consumers to pay (Cameron \& James, 1987; Ajzen, 1992), price elasticity of demand in global market (Harris, 1985; Haniotis, Baffes \& Ames, 1988), trade barriers (Cavusgil, 1996) and inflation in domestic and global markets (Kaldor, 1976; Gylfason, 1999; Borio \& Filardo, 2007). While talking about supply side perspective, natures of firm and industry come into picture. Nature of any industry and the firm operating in that industry can be characterized by amount of invested capital (Haar, Starr \& MacMillan, 1988; Manigart, Waele, Wright, Robbie, Desbrières, Sapienza \& Beekman, 2002), number of employees (Krugman, 1981; Hill \& Waterson, 1983; Datta, Guthrie \& Wright, 2005) and life cycle of output (Polli \& Cook, 1969; McGuinness \& Little, 1981; Day, 1981). Keeping apart these factors, presence of substitutes (Isard, 1977; Buschena \& Perloff, 1991) or complements (Bleaney, 1999; Gopinath, Pick \& Vasavada, 1999) also influence pricing decision to a huge extent. Considering the substitutes, role of differentiation factor also comes into picture (Hansen, Dibrell \& Down, 2006; Donnet, Weatherspoon \& Hoehn, 2007). Considering these factors, a conceptual optimization model has been designed in this paper, so that firm can optimize export pricing decision by looking at either demand or supply side of market. Review of the literature reveals that empirical analysis of aforementioned factors had been done on a standalone basis. However, the empirical analysis on the concept of service oriented export pricing objective has not been carried up so far.

Myers, Cavusgil \& Diamantopoulos (2002) tried to encompass demand side factors of export price. They have put emphasis on subjective matters like international experience of the firm and commitment to the venture. Nevertheless, they somewhat ignored supply side and service development cost considerations in their model. While describing export-pricing factors, Cavusgil (1988) focused majorly on supply side considerations, but ignored demand side. Walters (1989) tried to focus on transfer pricing strategies between firms while discussing about export pricing. However, considering firm has no development facility abroad, this phenomenon stands invalid. Existing literature focuses mainly on global market while standardizing export price. There is little literature available which talk about emphasizing on domestic market price optimization with a view to go away with export price (Kirpalani \& Macintosh, 1980; Bilkey, 1982; Koh \& Robicheaux, 1988). Therefore, optimization of domestic price of services can in turn lead to optimization of its export price, if export price is considered as a function of domestic price. This consideration is practical enough watching at the percentage of service export as a part of gross national product (GNP) for emerging economies. Given prevailed dynamism present in economic environment, monetary shocks can be visualized via incorporation of inflation-adjusted exchange rate along with domestic price level (Murphy, 1989; Klein, 1990). Hence, it can be used as a proxy measure for service oriented export-pricing mechanism. Forman \& Hunt (2005) have tried to encompass the demand and supply side considerations in their international strategic pricing model. With the use of likert scale, they 
empirically captured subjective elements in their model. However, their model failed to capture a number objective elements affecting pricing decision.

Considering existing literature on service oriented export pricing model, we have come across a set of research gaps, which are needed to be addressed, keeping in mind the criticality of export pricing decision. During the course of literature review, we have not come across any study, which has mulled over profit maximization model by encompassing demand and supply side of the market. Moreover, most of the objective decisive factors have not been considered so far in the literature, while modeling for service oriented export price. Therefore, need of a conceptual model encompassing objective factors from both demand and supply side has been identified. In this paper, it has been tried to formulate a conceptual model for service-oriented export pricing by looking at both demand and supply side considerations. Export price has been considered as a function of domestic price of service. Hence optimization of domestic price in both the cases in turn will lead towards optimization of export price for both the cases. For dynamic simulation purpose, a hypothetical example has been taken up. Based on the results of simulation, managerial solutions have been provided accordingly. Pricing objectives have also been aligned with the simulation results. Apparent gap of empirical analysis in export pricing objective domain in existing literature has been tried to be filled up with the help of this conceptual modeling and model testing of export pricing.

\section{Model Development}

Before starting off, following assumptions are made in order to go ahead with the model development:

- $\quad$ Export price set for the global market is directly dependent on price set for domestic market (Khan, 1974; Oskooeea \& Niroomand, 1998).

- $\quad$ Firm applies differential pricing mechanism.

- $\quad$ Domestic price is a continuous variable over a period of time (Kalman, Maier, Schwartz \& Whitcomb, 1981).

- $\quad$ Firm has no development facility abroad.

- $\quad$ No discounts are provided on service maintenance.

In order to go ahead with model development, let us consider these following variables:

$P_{d}=$ Price of service in domestic market

$P_{f}=$ Price of service in foreign market

$A_{d}=$ Willingness to pay in domestic market

$A_{f}=$ Willingness to pay in foreign market

$B_{d}=$ Price elasticity of demand in domestic market

$B_{f}=$ Price elasticity of demand in foreign market

$h=$ Services rendered for domestic market

$e=$ Services rendered for foreign market

$P_{o}=$ Price of substitute / complement in foreign market 
$b=$ Service Differentiation factor

$r=$ Exchange rate

$t=$ Amount of duty charged on the exported service

$x=$ Percentage of export price to be paid in terms of duty

$c=$ Service development cost per unit

$i_{d}=$ Inflation level in domestic market

$i_{f}=$ Inflation level in foreign market

$K=$ Capital employed by the firm

$L=$ Number of employees required to develop the service

$\alpha=$ Elasticity of capital

$\beta=$ Elasticity of labour

$\partial=$ Margin charged in foreign market

$T=$ Life cycle stage of the service

The demand function for domestic market can be denoted as per the following (Marshall, 1920):

$$
P_{d}=A_{d}-B_{d} h
$$

where, $B_{d} \in \mathbf{R}$.

In the similar fashion, demand function for foreign market can be denoted as per the following:

$$
P_{f}=A_{f}-B_{f} e+P_{o} b
$$

where, $B_{f} \in \mathbf{R}$.

Price in the foreign market can be defined as

$$
P_{f}=r P_{d}+\partial
$$

where, $\partial \in \mathbf{R}$.

Duty charged on the exported product can be defined as:

or,

$$
\begin{aligned}
& t=x P_{f} \\
& t=x\left(r P_{d}+\partial\right)
\end{aligned}
$$

where, $\mathrm{x} \in[0,1]$.

Production cost incurred by the firm is given by:

$$
\mathrm{C}=\mathrm{c}(\mathrm{e}+\mathrm{h})
$$

Hence profit made by the firm by selling product in domestic market, as well as foreign market is given by (Shoham, 1998): 


$$
\Pi=\mathrm{P}_{\mathrm{d}} \mathrm{h}+\mathrm{P}_{\mathrm{f}} \mathrm{e}-\mathrm{c}(\mathrm{e}+\mathrm{h})-\mathrm{et}
$$

Substituting the values from (1), (2), (3), and (4) into (6), we get:

$$
\begin{aligned}
\Pi= & \left(\mathrm{P}_{\mathrm{d}} / \mathrm{B}_{\mathrm{d}}\right)\left(\mathrm{A}_{\mathrm{d}}-\mathrm{P}_{\mathrm{d}}\right)+\left\{\left(\mathrm{r} \mathrm{P}_{\mathrm{d}}+\partial\right) / \mathrm{B}_{\mathrm{f}}\right\}\left(\mathrm{A}_{\mathrm{f}}+\mathrm{P}_{\mathrm{o}} \mathrm{b}-\mathrm{r} \mathrm{P}_{\mathrm{d}}-\partial\right) \\
& -\mathrm{c}\left\{\left(\mathrm{A}_{\mathrm{f}}+\mathrm{P}_{\mathrm{o}} \mathrm{b}-\mathrm{r} \mathrm{P}_{\mathrm{d}}-\partial\right) / \mathrm{B}_{\mathrm{f}}+\left(\mathrm{A}_{\mathrm{d}}-\mathrm{P}_{\mathrm{d}}\right) / \mathrm{B}_{\mathrm{d}}\right\} \\
& -\left\{\mathrm{x}\left(\mathrm{r} \mathrm{P}_{\mathrm{d}}+\partial\right) / \mathrm{B}_{\mathrm{f}}\right\}\left(\mathrm{A}_{\mathrm{f}}+\mathrm{P}_{\mathrm{o}} \mathrm{b}-\mathrm{r} \mathrm{P}_{\mathrm{d}}-\partial\right)
\end{aligned}
$$

where, $\mathrm{P}_{\mathrm{d}} \geq 0, \mathrm{P}_{\mathrm{f}}>0, \mathrm{r}>0, \mathrm{~A}_{\mathrm{d}} \geq 0, \mathrm{~A}_{\mathrm{f}}>0, \mathrm{c}>0, \mathrm{x}>0, \mathrm{e}>0, \mathrm{~h} \geq 0$.

Objective of the firm is to maximize this profit for any given domestic price, so that the optimized price level is also reflected in export price level. In order to go for optimization of the profit, (7) must be differentiated with respect to domestic price $\left(P_{d}\right)$.

$$
\begin{aligned}
& \frac{d \Pi}{d \mathrm{P}_{\mathrm{d}}}=\left(1 / \mathrm{B}_{\mathrm{d}}\right)\left(\mathrm{A}_{\mathrm{d}}-2 \mathrm{P}_{\mathrm{d}}\right)+\left(\mathrm{r} / \mathrm{B}_{\mathrm{f}}\right)\left(\mathrm{A}_{\mathrm{f}}+\mathrm{P}_{\mathrm{o}} \mathrm{b}-2 \mathrm{rP}_{\mathrm{d}}-2 \partial\right) \\
&+\mathrm{c}\left(\mathrm{r} / \mathrm{B}_{\mathrm{f}}+1 / \mathrm{B}_{\mathrm{d}}\right)-\left(\mathrm{rx} / \mathrm{B}_{\mathrm{f}}\right)\left(\mathrm{A}_{\mathrm{f}}+\mathrm{P}_{\mathrm{o}} \mathrm{b}-2 \mathrm{rP}_{\mathrm{d}}-2 \partial\right) \\
& \text { or, } \quad \frac{\partial^{2} \Pi}{\partial \mathrm{P}_{\mathrm{d}}^{2}}=-\left\{2 / \mathrm{B}_{\mathrm{d}}+2 \mathrm{r}^{2} / \mathrm{B}_{\mathrm{f}}(1-\mathrm{x})\right\}<0
\end{aligned}
$$

Second order condition for optimization is fulfilled in (9). It is clearly evident that at the optimum value of $P_{d}$ makes the first order condition illustrated at (8) to zero.

$$
\begin{aligned}
\frac{d \Pi}{d \mathrm{P}_{\mathrm{d}}}= & \left(1 / \mathrm{B}_{\mathrm{d}}\right)\left(\mathrm{A}_{\mathrm{d}}-2 \mathrm{P}_{\mathrm{d}}\right)+\left(\mathrm{r} / \mathrm{B}_{\mathrm{f}}\right)\left(\mathrm{A}_{\mathrm{f}}+\mathrm{P}_{\mathrm{o}} \mathrm{b}-2 \mathrm{r} \mathrm{P}_{\mathrm{d}}-2 \partial\right) \\
+ & \mathrm{c}\left(\mathrm{r} / \mathrm{B}_{\mathrm{f}}+1 / \mathrm{B}_{\mathrm{d}}\right)-\left(\mathrm{rx} / \mathrm{B}_{\mathrm{f}}\right)\left(\mathrm{A}_{\mathrm{f}}+\mathrm{P}_{\mathrm{o}} \mathrm{b}-2 \mathrm{r} \mathrm{P}_{\mathrm{d}}-2 \partial\right)=0 \\
\text { or, } \quad \mathrm{P}_{\mathrm{d}}= & {\left[\mathrm{B}_{\mathrm{f}}\left(\mathrm{A}_{\mathrm{d}}+\mathrm{c}\right)+\mathrm{r} \mathrm{B}_{\mathrm{d}}\left\{(1-\mathrm{x})\left(\mathrm{A}_{\mathrm{f}}+\mathrm{P}_{\mathrm{o}} \mathrm{b}+\partial\right)+\mathrm{c}\right\}\right] } \\
& / 2\left[\mathrm{~B}_{\mathrm{f}}+\mathrm{r}^{2} \mathrm{~B}_{\mathrm{d}}(1-\mathrm{x})\right]
\end{aligned}
$$

Till now, model was assuming that domestic and foreign economies are stable at any particular point of time. Assuming dynamism in the environment, there will be inflation prevailed in domestic market (Kouri, 1976; Branson, Halttunen \& Masson, 1977; Calvo \& Rodriguez, 1977; Niehans, 1977; Dornbusch \& Fischer, 1980; Rodriguez, 1980). Let us consider that level of domestic inflation $i_{d}$ and level of domestic inflation $i_{f}$ are prevailed in the market for $t$ period. This will affect the exchange rate $(r)$ directly, as domestic currency will be weakened or strengthened accordingly (Hooper \& Morton, 1982; Mussa, 1982). In view of this discussion, exchange rate after $T$ period can be defined as:

$$
r_{t}=r\left[\left(1+i_{f}\right) /\left(1+i_{d}\right)\right]^{T}
$$

Incorporating time factor and (11) into domestic price model in (10), we get: 


$$
\begin{aligned}
P_{d}= & {\left[B_{f}\left(A_{d}+c\right)+B_{d} r\left\{\begin{array}{c}
\left(1+i_{f}\right) \\
/\left(1+i_{d}\right)
\end{array}\right\}^{T}\left\{\begin{array}{c}
(1-x) A_{f}+(1-x) P_{o} b \\
\left.\left(1+i_{f}\right)^{T}+(1-x) \partial+c\right)
\end{array}\right\}\right] } \\
& /\left[B_{f}\left(1+i_{d}\right)^{T}+r^{2} B_{d}(1-x)\left\{\begin{array}{c}
\left(1+i_{f}\right)^{2} \\
/\left(1+i_{d}\right)
\end{array}\right\}^{T}\right]
\end{aligned}
$$

So far, we have looked at the model development from international transaction and demand side economics perspective. However, it is also important to look at the model from domestic production and supply side economics perspective. Looking from that dimension, production function of the firm can be defined in terms of Cobb-Douglas form (Cobb \& Douglas, 1928):

$$
\mathrm{Q}=\mathrm{K}^{\alpha} \mathrm{L}^{\beta}
$$

Substituting values from (1) and (2), we get:

$$
\left(\mathrm{A}_{\mathrm{d}}-\mathrm{P}_{\mathrm{d}}\right) / \mathrm{B}_{\mathrm{d}}+\left(\mathrm{A}_{\mathrm{f}}+\mathrm{P}_{\mathrm{o}} \mathrm{b}-\mathrm{P}_{\mathrm{f}}\right) / \mathrm{B}_{\mathrm{f}}=\mathrm{K}^{\alpha} \mathrm{L}^{\beta}
$$

Incorporating exchange rate and inflation factors in (14), we get:

$$
\begin{aligned}
P_{d}= & {\left[A_{d} / B_{d}+\left\{A_{f}+b P_{o}\left(1+i_{f}\right)^{T}-\partial\right\} / B_{f}-K^{\alpha} L^{\beta}\right] } \\
& /\left[\left(1+i_{d}\right)^{T} / B_{d}+\left(r / B_{f}\right)\left\{\begin{array}{l}
\left(1+i_{f}\right) \\
/\left(1+i_{d}\right)
\end{array}\right\}\right]
\end{aligned}
$$

\section{Discussion}

\section{a. Academic Implications}

So far, we have developed the models for domestic price optimization for demand and supply side. In the due course of the development, we have two expressions for domestic price in (12) and (15). The discussion regarding academic implications of this model to be followed will be two-folded.

In order to go ahead with the discussion, let's consider a hypothetical example. Let us assume that, willingness to pay in domestic market is $A_{d}=$ Rs. 10 and in foreign market is $A_{f}=$ Rs. 12. Price elasticity for both the markets are $B_{d}=5$ and $B_{f}=6$ respectively. Quantity produced for domestic market is $h=100$ and for foreign market is $e=200$. Differentiation factor $b=5$. Price of the substitute or complement good is $P_{o}=$ Rs. 30. Exchange rate is given by $r=40$. Amount of duty charged as part of export price is $x=50 \%$. Unit cost production is given by $c=$ Rs. 10. Inflation rates prevailed in the markets are $i_{d}=3 \%$ and $i_{f}=5 \%$. Invested capital is $K=$ Rs. 40 and number of labors employed is $L=5$. Considering the industry works under constant returns to scale, elasticity factors for production are given by $\alpha=0.6$ and $\beta=0.4$. Premium 
charged in foreign market is $\partial=$ Rs. 10 . Time given is $T=5$ periods. Further discussion will be built upon this example and making suitable changes in accordance with requirement for dynamic simulation. All of the simulations are conducted to test extreme boundary conditions, which are in accordance with the values assumed in aforementioned example. Changing the values of this example will change the boundary conditions as well, and testing of the boundary conditions has been carried out for all the scenarios by altering the values in the example, results of which are recorded through Table 1 to Table 9.

\section{a. Demand side analysis}

In light of the hypothetical example posed, $P_{d}$ comes out to be Rs. 1.58. Accordingly the export price $P_{f}$ is given by Rs. 73.32. Now keeping all other factors constant, dynamic simulation has been carried up by unitarily changing $i_{f}$ and $i_{d}$. Incorporation of inflation factors provides an insight about impact of change in economic environment on domestic price. Inflation in both the economies affect domestic product price in different ways (Junz \& Rhomberg, 1973; Bredahl, Meyers \& Collins, 1979). Vigilant look at (12) shows:

$$
\frac{d \mathrm{P}_{\mathrm{f}}}{d \mathrm{i}_{\mathrm{f}}}>\frac{d \mathrm{P}_{\mathrm{f}}}{d \mathrm{i}_{\mathrm{d}}}
$$

Recorded results of simulation in Table 1 depict the phenomenon shown in (16). For any given foreign market inflation, rise in domestic market inflation increases export price, as it weakens domestic currency and raises exchange rate (Kravis \& Lipsey, 1977; Stockman, 1980). On the contrary, for any given domestic market inflation, rise in foreign market inflation reduces export price, as it strengthens domestic currency and lowers exchange rate (Edwards, 1989; Devereux \& Yetman, 2002).

\section{[Insert Table 1 (Changes in export price due to changes in domestic and foreign market inflations considering demand side scenario) here]}

Going ahead with the simulation, effect of duty on export needed to be checked as well. In order to check this, it is needed to go back to the hypothetical example we have started with. Keeping all other factors constant, $x$ has been gradually increased by $10 \%$. Results are recorded in Table 2. It clearly indicates that more duty imposed on export price in turn increases the export price (Balassa, 1978; Panagariya \& Gupta, 1998; Hoekman, Ng \& Olarreaga, 2002; Martin \& Anderson, 2012). Hence, it works as a filter mechanism to put a cap on exporting of goods and services. Higher price in foreign market reduces competitiveness of the product (Paulino, 2002; Husain, 2003). So policy level decisions must be made in consultation with state to come up with an optimal level of duty to be imposed on goods or services to be exported or imported.

[Insert Table 2 (Changes in export price due to changes in percentage of duty) here] 
Price elasticity of demand prevailed in both economies play a major role in determining the export price (Orcutt, 1950; Houthakker \& Magee, 1969; Knetter, 1989). Continuing our hypothetical example, both of the elasticities in domestic and foreign market have been unitarily increased, keeping all other factors constant. Results are recorded in Table 3. For any given value of elasticity in domestic market, if elasticity in foreign market is increased, then export price falls if domestic market is negatively elastic and increases, if positively elastic. Similar phenomenon can be seen if elasticity in foreign market is kept constant and elasticity in domestic market is unitarily increased accordingly (Haberler, 1949; Dornbusch, 1987). Hence, firm should choose to export products on the basis the elasticities prevailed in domestic as well foreign market for that particular product.

\section{[Insert Table 3 (Changes in export price due to changes in price elasticities in both the economies considering demand side scenario) here]}

Whenever firm will place product in foreign market, it will face two types of products. One type will be substitute product, whereas another will be complementary product (Floyd, 1965; Khan \& Knight, 1988). Nature of $P_{o}$ in (12) will be altered accordingly (Johnson, 1954). According to nature of complementary and substitute products,

For complementary products: $\frac{d \mathrm{P}_{\mathrm{d}}}{d \mathrm{P}_{\mathrm{o}}}>0$

For substitute products: $\quad \frac{d \mathrm{P}_{d}}{d \mathrm{P}_{\mathrm{o}}}<0$

This brings forth another important insight about the differentiation factor (b). This shows that equation (12) depicting domestic product price is inclusive in nature, which incorporates both the complementary and substitute products (Yntema, 1928; Brander \& Spencer, 1985; Corsetti \& Dedola, 2005). Conditions shown in (17) confirm that formulation of domestic product price needs recalculation (Bulow, Geanakoplos \& Klemperer, 1985; Majerus, 1988; Markusen, 1988). Incorporating aforementioned conditions in (12) provides with new equations for domestic price given two types of products.

$$
\begin{aligned}
& \left.P_{d}=\left[B_{f}\left(A_{d}+c\right)+B_{d} r\left\{\begin{array}{l}
\left(1+i_{f}\right) \\
/\left(1+i_{d}\right)
\end{array}\right\}^{T}\left\{(1-x) A_{f}+(1-x) \partial+c\right)\right\}\right] \\
& /\left[B_{f}\left(1+i_{d}\right)^{T}+r^{2} B_{d}(1-x)\left\{\begin{array}{c}
\left(1+i_{f}\right)^{2} \\
/\left(1+i_{d}\right)
\end{array}\right\}^{\mathrm{T}}\right]
\end{aligned}
$$


and,

$$
P_{d}=\left[B_{f}\left(A_{d}+c\right)+B_{d} r\left\{\begin{array}{l}
\left(1+i_{f}\right) \\
/\left(1+i_{d}\right)
\end{array}\right\}^{T}\left\{\begin{array}{l}
(1-x) A_{f}-(1-x) P_{o} b \\
\left.\left(1+i_{f}\right)^{T}+(1-x) \partial+c\right)
\end{array}\right\}\right]
$$

$$
/\left[B_{f}\left(1+i_{d}\right)^{T}+r^{2} B_{d}(1-x)\left\{\begin{array}{l}
\left(1+i_{f}\right)^{2} \\
/\left(1+i_{d}\right)
\end{array}\right\}^{\mathrm{T}}\right]
$$

Equation (18) denotes optimized domestic price equation considering the presence of complementary product and (19) denotes optimized domestic price equation considering the presence of substitute product, in foreign market.

Next set of dynamic simulation is carried up to show the effect of willingness to pay in both the economies. In continuation with the hypothetical example, $A_{d}$ and $A_{f}$ were gradually increased by 10, whereas all other factors have been kept constant. Results are recorded in Table 4. They are quite obvious in nature. Rise in export price was resulted by rise in willingness to pay for all the cases (Gil, Gracia \& Sánchez, 2000; Simonson \& Drolet, 2004; Noussair, Robin \& Ruffieux, 2004). This enables firms to go for market skimming pricing (Liu, 2010).

[Insert Table 4 (Changes in export price due to changes in willingness to pay in both the economies considering demand side scenario) here]

Last set of dynamic simulation in this section was carried up to demonstrate the effect of exchange rate on export price. In the example, exchange rate has been gradually changed by 10 units and results are recorded in Table 5. It shows that a stronger domestic currency diminishes the competitiveness of product in monetary terms (Krugman, 1986; Betts \& Devereux, 2000). Higher exchange rate i.e. weaker domestic currency allows firm to lower down its export price (Cushman, 1983; Arize, Osang \& Slottje, 2000).

[Insert Table 5 (Changes in export price due to changes in exchange rate) here]

\section{b. Supply side analysis}

In light of the hypothetical example posed, $P_{d}$ comes out to be Rs. 0.54 . Accordingly the export price $P_{f}$ is given by Rs. 31.48. But a vigilant look at (15) brings forth condition for a real value of export price. It is given by:

$$
A_{d}\left(B_{f} / B_{d}\right)+A_{f}+b P_{o}\left(1+i_{f}\right)^{T}>\partial+B_{f} K^{\alpha} L^{\beta}
$$

This provides a clear insight about initial investment plan and margin decision given the economic conditions of both the markets. Putting values from the hypothetical example, left hand side of (20) comes out to be 23.14. Keeping all other values constant, dynamic simulation has been carried up for various combinations of right hand side of (20). Results are recorded in Table 6. It is visible from the result that increasing margin amount in turn reduces average number of labours employed. Given constant return to scale, there is a visible trade-off between 
capital and labour employed. This provides a depiction about policy level decisions regarding the investment and margin setting of the service, while the firm going global.

[Insert Table 6 (Mutual changes in capital, number of labour and margin) here]

Like previous case, dynamic simulation has been carried up to show effect of inflation on export price. Values of $i_{d}$ and $i_{f}$ are unitarily increased in the due course and export price values are recorded in Table 7 . Findings are contradicting in nature with respect to the previous case. Here for any given value of $i_{d}$, value of $P_{f}$ rises with increase in $i_{f}$. Similarly, for any given value of $i_{f}$, value of $P_{f}$ rises with increase in $i_{d}$. From supply side perspective, inflation gets similar kind of treatment for both the economies. Therefore, extreme inflationary pressure in domestic market is not a preferable condition for service providers, whereas considering the demand situate of the consumers in international market, inflationary pressure in international market is preferable.

\section{[Insert Table 7 (Changes in export price due to changes in domestic and foreign market} inflations considering supply side scenario) here]

Price elasticity of demand prevailed in both economies play a major role in determining the export price. Continuing our hypothetical example, both elasticities in domestic and foreign market has been unitarily increased, keeping all other factors constant. Results are recorded in Table 8. For any given value of elasticity in domestic market, if elasticity in foreign market is increased, then export price falls. But if elasticity in foreign market is kept negative and elasticity in domestic market is unitarily increased, then export will rise initially, till $B_{d}$ is negative. Once it reaches positive value, export price falls suddenly and then again, it starts to rise. Treatment changes inversely when elasticity in foreign market attains positive value. This result is contradicting compared to result in previous case. Hence firm should choose to export products based on the elasticities prevailed in domestic as well foreign market for that particular product.

\section{[Insert Table 8 (Changes in export price due to changes in price elasticities in both the economies considering supply side scenario) here]}

Next set of dynamic simulation is carried up to show the effect of willingness to pay in both the economies. In continuation with our hypothetical example, $A_{d}$ and $A_{f}$ were gradually increased by 10, whereas all other factors have been kept constant. Results are recorded in Table 9. They are obvious in nature. Rise in export price was resulted by rise in willingness to pay for all the cases. This result is in harmony with the previous scenario, and as well as the literature on demand side analysis of services (Abu-ELSamen, Akroush, Al-Khawaldeh \& Al-Shibly, 2011).

[Insert Table 9 (Changes in export price due to changes in willingness to pay in both the economies considering supply side scenario) here]

Briefly, all the treatments are recorded in Table 10. It shows a comprehensive and comparative picture of all the simulations done so far. Depending on economic factors of market, 
pricing objectives change. Table 11 depicts the pricing strategies suggested given willingness of consumers to pay in both the markets, and the results are extension of the works previously carried out by researchers on various pricing strategies (Xing \& Tang, 2004; Lii \& Lee, 2005; Abdallah \& Maghrabi, 2009). Low willingness to pay in both markets results in low export price, whereas high willingness to pay in any of the two markets results in transient high export price. High willingness to pay in both the markets results in consistent high export price. Pricing decisions are aligned with these results. Similarly, pricing decisions are also aligned with price elasticity of demand in both the markets. Suggested alignment results are recorded in Table 12. Combination of both of these results can in turn answer the question of optimum export price setting in global market.

\section{[Insert Table 10 (Behaviour of export price with respect to constituent variables in both cases) here]}

[Insert Table 11 (Pricing strategies based on willingness to pay in both markets) here]

\section{[Insert Table 12 (Pricing strategies based on price elasticity of demand in both markets) here]}

\section{b. Industrial Implications}

So far, for academic implication purpose, we have used a hypothetical scenario in order to demonstrate the working of the model, as well as to test the boundary conditions. However, devoid of providing with the example of industrial implications of the model, it may prove out to be tough to illustrate its practical relevance. In this section, we will discuss the industrial implications of this model, considering various conditions for a service industry, which is operating in a developing nation.

To talk about the industrial implications of this model, let us take the example of any information technology (IT) service provider, which is indulged into development of software solutions for various other industries. Due to control of the life cycles of their products, they are able to control their product price in the international market. Choice of latest technologies can possibly enable them to reduce capital employment, and at the same time, depending on the size of deployment, they can flexibly alter their labour force by utilizing their bench strength. Higher return on capital and labour can enable them to reduce their service price in international market. However, considering the dynamism in international market, it is crucial for them to alter their pricing strategies, based on the prevailing rate of inflation and exchange rates in domestic and international market. Depending on the international relations, price of their products also change, as percentage of export price to be paid in terms of duty is solely dependent on the relation with other nations. Based on these and additional socio-political factors, price elasticity of demand of the service and willingness to pay for the service changes accordingly. Therefore, it has been largely seen that IT firms always try to capture clients from domestic market, as it can always provide them with an opportunity for hedging against the unforeseen risk in the international market. If we look at the revenue structure of the renowned IT firms across India, 
we can visualize that leaving Infosys apart most of them are highly dependent on clients from domestic market. This can also help them in setting their export price in the most competitive manner, and following the similar kinds of strategies in both the markets.

If we compare this pricing behaviour of Indian IT firms with the results being received from our model, then we can understand the behaviour of our model. A closer look at Table 10 can provide us with the substantiation of the aforementioned details regarding IT industry in India. Considering the development and maintenance services being provided by the IT firms in India, the associations established and depicted in Table 10 can find their relevance. With the advent of more sophisticated object oriented technologies, IT firms can play a very significant tradeoff between capital employment and labour force (Gans \& Stern, 2003), and in turn this tradeoff can assist them in lowering the price of their services in domestic, as well as international market. Inverse associations found in capital-export price and labour force-export price associations demonstrate the tradeoff behaviour of IT firms, while setting the price for international market. A strong presence in the domestic market allows them to enjoy low price elasticity of demand and a higher willingness to pay, and based on this foundation, they can optimize export price of their services. Having competitive bench strengths allow them to offer low hourly billing rate, which is reflected in the service price in international markets, as for the projects they acquire in the international markets are majorly developmental in nature, unlike the maintenance projects in domestic markets. Therefore, the inverse association between labour employment and export price holds in this scenario. Now, looking at the Indian IT industry at large, we can experience that attributing to $\mathrm{Y} 2 \mathrm{~K}$ bug issue, India started to receive outsourced projects, and that was the time, when Indian IT industry started to flourish (Arora, Arunachalam, Asundi \& Fernandes, 2001). Majority of the revenue of Indian IT firms come via the route of outsourcing, and the exchange rate spread adds to their profit amount. That is the reason, consideration of inflationary movements in the economy is critical for maintaining the stream of revenue. Too much of inflation in the domestic market can in turn increase the real wage rate, which is reflected in higher price of service in domestic market, and subsequently international market. Compared to this, inflationary pressure in the international market is preferable for reducing the service price, as that will reduce the competitiveness of the services being offered by the players in those countries, and demand for more cost competitive services will reduce their price elasticity of demand and increase willingness to pay for the services being offered by the players from other nations. Therefore, given the stipulated conditional aspects, it becomes advantageous for the IT firms to enter the international markets during the higher inflationary situates. The effects of inflation in domestic and international markets shown in Table 10 are in accordance with the aforementioned arguments. Therefore, we may infer that the developed model can be demonstrated for any service industry operating in any developing nation, which is performing business with any developed nation.

\section{Conclusion}


The conceptual model for export price optimization has been developed so far. Set of systematic simulations have shown the viability of this model, when it is applied to nearly real world situations. This model provides an insight for those managers, who want to lay their foot beyond the national boundaries. Extensive (though not complete) factors of dynamism have provided the model with robustness and flexibility. Incorporation of objective and subjective factors has made the model ready for empirical purpose, which has already been showcased with the help of our hypothetical example. Hence, this paper contributes in the field of export pricing decision making. Moving one-step ahead of the literature, this contribution seems to be significant in the field of economic analysis of export pricing.

In isolation, effects of all the parameters considered in this model have been well established in the literature. However, when any firm will be taking any price related decision regarding exporting its services, interplay of all those factors will come into picture, and that was the part missing largely in literature. Aligning pricing objectives along with the combinations of decision parameters is a major contribution of this paper. Nevertheless, the findings may be considered with a pinch of salt, as they are established based on service based export pricing environment.

As business environment in global scenario is dynamic in nature, continuous time optimization methodology has been adopted, as we are not considering the sustainability of the same decision over a longer period. However, discrete time optimization can be taken up in the same model, if the effect of a series of decisions is scrutinized. We also have not considered transfer-pricing mechanism within the firm, as its effect will be visible in the final domestic price of the service offered by firm. More flexibility can be incorporated in the model, if a range of domestic price is considered over the singular domestic price.

Henceforth, limitations regarding development of this model can in turn result in future scope of research. Incorporation of these factors can make this model more robust and flexible in nature, so that it can be generalized for any types of industry, given any kind of economic scenario. Fulfillment of this research objective can augment export pricing decision in dynamic global market scenario to a great extent. 


\section{Reference}

Abdallah, W.M., and Maghrabi, A.S. (2009), "Do multinational companies have effective transfer pricing systems of intangible assets and e-commerce?", International Journal of Commerce and Management, Vol. 19 No. 2, pp. 115-126.

Abu-ELSamen, A.A., Akroush, M.N., Al-Khawaldeh, F.M., and Al-Shibly, M.S. (2011), "Towards an integrated model of customer service skills and customer loyalty: The mediating role of customer satisfaction", International Journal of Commerce and Management, Vol. 21 No. 4, pp. 349-380.

Ajzen, I. (1992), “Contingent Value Measurement: On the Nature and Meaning of Willingness to Pay”, Journal of Consumer Psychology, Vol. 1 No. 4, pp. 297-316.

Arize, A.C., Osang, T. and Slottje, D.J. (2000), "Exchange-Rate Volatility and Foreign Trade: Evidence from Thirteen LDC's”, Journal of Business \& Economic Statistics, Vol. 18 No. 1, pp. 10-17.

Arora, A., Arunachalam, V.S., Asundi, J., and Fernandes, R. (2001), "The Indian software services industry", Research Policy, Vol. 30 No. 8, pp. 1267-1287.

Balassa, B. (1978), "Export Incentives and Export Performance in Developing Countries: A Comparative Analysis", Review of World Economics, Vol. 114 No. 1, pp. 24-61.

Betts, C. and Devereux, M.B. (2000), "Exchange Rate Dynamics in a Model of Pricing-ToMarket”, Journal of International Economics, Vol. 50 No. 1, pp. 215-244.

Bleaney, M. (1999), "Trade reform, macroeconomic performance and export growth in ten Latin American countries, 1979-95", The Journal of International Trade \& Economic Development: An International and Comparative Review, Vol. 8 No. 1, pp. 89-105.

Bilkey, W.J. (1982), "Variables Associated with Export Profitability”, Journal of International Business Studies, Vol. 13 No. 2, pp. 39-55.

Borio, C.E.V. and Filardo, A.J. (2007), "Globalisation and Inflation: New Cross-Country Evidence on the Global Determinants of Domestic Inflation", working paper, Bank for International Settlements, Switzerland, 10 May.

Brander, J.A. and Spencer, B.J. (1985), "Export Subsidies and International Market Share Rivalry", Journal of International Economics, Vol. 18 No. 1-2, pp. 83-100.

Branson, W.H., Halttunen, H. and Masson, P. (1977), "Exchange Rates in the Short Run: The Dollar-Deutschemark Rate", European Economic Review, Vol. 10, pp. 303-324.

Bredahl, M.E., Meyers, W.H. and Collins, K.J. (1979), "The Elasticity of Foreign Demand for U.S. Agricultural Products: The Importance of the Price Transmission Elasticity", American Journal of Agricultural Economics, Vol. 61 No. 1, pp. 58-63. 
Bulow, J.I., Geanakoplos, J.D. and Klemperer, P.D. (1985), "Multimarket Oligopoly: Strategic Substitutes and Complements", Journal of Political Economy, Vol. 93 No. 3, pp. 488511.

Buschena, D.E. and Perloff, J.M. (1991), "The Creation of Dominant Firm Market Power in the Coconut Oil Export Market”, American Journal of Agricultural Economics, Vol. 73 No. 4, pp. 1000-1008.

Calvo, G.A. and Rodriguez, C.A. (1977), "A Model of Exchange Rate Determination under Currency Substitution and Rational Expectations", Journal of Political Economy, Vol. 85 No. 3, pp. 617-625.

Cameron, T.A. and James, M.D. (1987), "Estimating Willingness to Pay from Survey Data: An Alternative Pre-Test-Market Evaluation Procedure”, Journal of Marketing Research, Vol. 24 No. 4, pp. 389-395.

Cavusgil, S.T. (1988), "Unraveling the Mystique of Export Pricing”, Business Horizons, Vol. 31 No. 3, pp. 54-63.

Cavusgil, S.T. (1996), "Pricing for Global Markets", Columbia Journal of World Business, Vol. 31, pp. 67-78.

Cobb, C.W. and Douglas, P.H. (1928), “A Theory of Production”, American Economic Review, Vol. 18 No. 1, pp. 139-165.

Corsetti, G. and Dedola, L. (2005), "A Macroeconomic Model of International Price Discrimination”, Journal of International Economics, Vol. 67 No. 1, pp. 129-155.

Cushman, D.O. (1983), "The Effects of Real Exchange Rate Risk on International Trade", Journal of International Economics, Vol. 15 No. 1-2, pp. 45-63.

Datta, D.K., Guthrie, J.P. and Wright, P.M. (2005), "Human Resource Management And Labor Productivity: Does Industry Matter?”, Academy of Management Journal, Vol. 48 No. 1, pp. 135-145.

Day, G.S. (1981), "The Product Life Cycle: Analysis and Applications Issues", Journal of Marketing, Vol. 45 No. 4, pp. 60-67.

Devereux, M.B. and Yetman, J. (2002), "Price Setting and Exchange Rate Pass-Through: Theory and Evidence", working paper, Hong Kong Institute for Monetary Research, Hong Kong, 29 October.

Domowitz, I., Hubbard, R.G. and Petersen, B.C. (1986), "Business Cycles and the Relationship between Concentration and Price-Cost Margins", The Rand Journal of Economics, Vol. 17 No. 1, pp. 1-17.

Donnet, M.L., Weatherspoon, D.D. and Hoehn, J.P. (2007), "What Adds Value in Specialty Coffee? Managerial Implications from Hedonic Price Analysis of Central and South American E-Auctions", International Food and Agribusiness Management Review, Vol. 10 No. 3, pp. 1-18. 
Dornbusch, R. (1987), "Exchange Rates and Prices”, American Economic Review, Vol. 77 No. 1, pp. 93-106.

Dornbusch, R. and Fischer, S. (1980), "Exchange Rates and the Current Account", American Economic Review, Vol. 70 No. 5, pp. 960-971.

Edwards, S. (1989), "Exchange Rate Misalignment in Developing Countries", World Bank Research Observer, Vol. 4 No. 1, pp. 3-21.

Floyd, J.E. (1965), "The Overvaluation of the Dollar: A Note on the International Price Mechanism", American Economic Review, Vol. 55 No. 1-2, pp. 95-107.

Forman, H. and Hunt, J.M. (2005), "Managing the Influence of Internal and External Determinants on International Industrial Pricing Strategies", Industrial Marketing Management, Vol. 34 No. 2, pp. 133-146.

Gans, J.S., and Stern, S. (2003), "The product market and the market for 'ideas': commercialization strategies for technology entrepreneurs", Research Policy, Vol. 32 No. 2, pp. 333-350.

Gil, J.M., Gracia, A. and Sánchez, M. (2000), "Market Segmentation and Willingness to Pay for Organic Products in Spain", International Food and Agribusiness Management Review, Vol. 3 No. 2, pp. 207-226.

Gopinath, M., Pick, D. and Vasavada, U. (1999), "The Economics of Foreign Direct Investment and Trade with an Application to the U.S. Food Processing Industry", American Journal of Agricultural Economics, Vol. 81 No. 2, pp. 442-452.

Gylfason, T. (1999), "Exports, Inflation and Growth", World Development, Vol. 27 No. 6, pp. 1031-1057.

Haar, N.E., Starr, J. and MacMillan, I.C. (1988), "Informal Risk Capital Investors: Investment Patterns On the East Coast of the U.S.A", Journal of Business Venturing, Vol. 3 No. 1, pp. 11-29.

Haberler, G. (1949), "The Market for Foreign Exchange and the Stability of the Balance of Payments A Theoretical Analysis", Kyklos, Vol. 3 No. 3, pp. 193-218.

Haniotis, T., Baffes, J. and Ames, G.C.W. (1988), "The Demand and Supply of U.S. Agricultural Exports: The Case of Wheat, Corn, and Soybeans", Southern Journal of Agricultural Economics, Vol. 20 No. 2, 45-55.

Hansen, E., Dibrell, C. and Down, J. (2006), "Market Orientation, Strategy, and Performance in the Primary Forest Industry”, Forest Science, Vol. 52 No. 3, pp. 209-220.

Harris, R. (1985), "Why Voluntary Export Restraints Are 'Voluntary"”, The Canadian Journal of Economics, Vol. 18 No. 4, pp. 799-809.

Hill, M. and Waterson, M. (1983), "Labor-Managed Cournot Oligopoly and Industry Output", Journal of Comparative Economics, Vol. 7 No. 1, pp. 43-51. 
Hoekman, B., Ng, F. and Olarreaga, M. (2002), "Eliminating Excessive Tariffs on Exports of Least Developed Countries", World Bank Economic Review, Vol. 16 No. 1, pp. 1-21.

Hooper, P. and Morton, J. (1982), "Fluctuations in the Dollar: A Model of Nominal and Real Exchange Rate Determination", Journal of International Money and Finance, Vol. 1, pp. 39-56.

Houthakker, H.S. and Magee, S.P. (1969), "Income and Price Elasticities in World Trade", The Review of Economics and Statistics, Vol. 51 No. 2, pp. 111-125.

Husain, I. (2003), "Pakistan's Export Competitiveness in Global Markets”, paper presented at the Seminar on Export-led Growth Strategy organized by the Export Promotion Bureau, 27 May, Lahore, Pakistan, available at: http://sbp.org.pk/about/speech/2003/29-may-032.pdf (accessed 19 November 2013).

Isard, P. (1977), "How Far Can We Push the "Law of One Price”?", American Economic Review, Vol. 67 No. 5, pp. 942-948.

Johnson, H.G. (1954), "Increasing Productivity, Income-Price Trends and the Trade Balance", The Economic Journal, Vol. 64 No. 255, pp. 462-485.

Joskow, P.L. (1973), "Pricing Decisions of Regulated Firms: A Behavioral Approach", The Bell Journal of Economics and Management Science, Vol. 4 No. 1, pp. 118-140.

Junz, H.B. and Rhomberg, R.R. (1973), "Price Competitiveness in Export Trade among Industrial Countries", American Economic Review, Vol. 63 No. 2, pp. 412-418.

Kaldor, N. (1976), "Inflation and Recession in the World Economy", The Economic Journal, Vol. 86 No. 344, pp. 703-714.

Kalish, S. (1983), "Monopolist Pricing with Dynamic Demand and Production Cost", Marketing Science, Vol. 2 No. 2, pp. 135-159.

Kalman, J.C., Maier, S.F., Schwartz, R.A. and Whitcomb, D.K. (1981), "Transaction Costs, Order Placement Strategy, and Existence of the Bid-Ask Spread", Journal of Political Economy, Vol. 89 No. 2, pp. 287-305.

Khan, M.S. (1974), "Import and Export Demand in Developing Countries", Staff Papers International Monetary Fund, Vol. 21 No. 3, pp. 678-693.

Khan, M.S. and Knight, M.D. (1988), "Important Compression and Export Performance in Developing Countries", The Review of Economics and Statistics, Vol. 70 No. 2, pp. 315321.

Kirpalani, V.H. and Macintosh, N.B. (1980), "International Marketing Effectiveness of Technology-Oriented Small Firms”, Journal of International Business Studies, Vol. 11 No. 3, pp. 81-90.

Klein, M.W. (1990), "Macroeconomic Aspects of Exchange Rate Pass Through", Journal of International Money and Finance, Vol. 9 No. 4, pp. 376-387. 
Knetter, M.M. (1989), "Price Discrimination by U.S. and German Exporters", American Economic Review, Vol. 79 No. 1, pp. 198-210.

Koh, A. and Robicheaux, R.A. (1988), "Variations in Export Performance Due to Differences in Export Marketing Strategy: Implications for Industrial Marketers”, Journal of Business Research, Vol. 17 No. 3, pp. 249-258.

Kortge, G.D., Okonkwo, P., Burley, J. and Kortge, J.D. (1994), "Linking Experience, Product Life Cycle, and Learning Curves: Calculating the Perceived Value Price Range", Industrial Marketing Management, Vol. 23 No. 3, pp. 221-228.

Kouri, P.J.K. (1976), "The Exchange Rate and the Balance of Payments in the Short Run and in the Long Run: A Monetary Approach", Scandinavian Journal of Economics, Vol. 78 No. 2, pp. 280-304.

Kravis, I.B. and Lipsey, R.E. (1977), "Export Prices and the Transmission of Inflation", American Economic Review, Vol. 67 No. 1, pp. 155-163.

Krugman, P.R. (1981), "Intraindustry Specialization and the Gains from Trade", Journal of Political Economy, Vol. 89 No. 5, pp. 959-973.

Krugman, P.R. (1986), "Pricing to Market when the Exchange Rate Changes", working paper, National Bureau of Economic Research, Cambridge, May.

Lii, D.Y.S., and Lee, M. (2005), "Consumers' evaluations of online reference price advertisement", International Journal of Commerce and Management, Vol. 15 No.2, pp. $101-112$.

Liu, H. (2010), "Dynamics of Pricing in the Video Game Console Market: Skimming or Penetration?", Journal of Marketing Research, Vol. 47 No. 3, pp. 428-443.

Majerus, D.W. (1988), "Price vs. Quantity Competition in Oligopoly Supergames”, Economics Letters, Vol. 27 No. 3, pp. 293-297.

Manigart, S., Waele, K.D., Wright, M., Robbie, K., Desbrières, P., Sapienza, H.J. and Beekman, A. (2002), "Determinants of required return in venture capital investments: a five country study", Journal of Business Venturing, Vol. 17 No. 4, pp. 291-312.

Markusen, J.R. (1988), "Trade Policy with Increasing Returns and Imperfect Competition: Contradictory Results from Competing Assumptions", Journal of International Economics, Vol. 24 No. 3-4, pp. 299-316.

Marshall, A. (1920), Principles of Economics, Macmillan, London, England.

Martin, W. and Anderson, K. (2012), "Export Restrictions and Price Insulation During Commodity Price Booms", American Journal of Agricultural Economics, Vol. 94 No. 2, pp. 422-427. 
McGuinness, N.W. and Little, B. (1981), "The Influence of Product Characteristics on the Export Performance of New Industrial Products", Journal of Marketing, Vol. 45 No. 2, pp. 110-122.

Montgomery, A.L. and Rossi, P.R. (1999), "Estimating Price Elasticities with Theory-Based Priors", Journal of Marketing Research, Vol. 36 No. 4, pp. 413-423.

Monroe, K.D. (1990), Pricing: Making Profitable Decisions, McGraw-Hill, New York, NY.

Murphy, R.G. (1989), "Import Pricing and the Trade Balance in a Popular Model of Exchange Rate Determination", Journal of International Money and Finance, Vol. 8 No. 3, pp. 345-357.

Mussa, M. (1982), “A Model of Exchange Rate Dynamics”, Journal of Political Economy, Vol. 90 No. 1, pp. 74-104.

Myers, M.B., Cavusgil, S.T. and Diamantopoulos, A. (2002), "Antecedents and Actions of Export Pricing Strategy: A Conceptual Framework and Research Propositions", European Journal of Marketing, Vol. 36 No. 1, pp. 159-188.

Niehans, J. (1977), "Exchange Rate Dynamics with Stock / Flow Interaction", Journal of Political Economy, Vol. 85 No. 6, pp. 1245-1258.

Noble, P. and Gruca, T.S. (1999), "Industrial pricing: Theory and managerial practice", Marketing Science, Vol. 18 No. 3, pp. 435-454.

Noussair, C., Robin, S. and Ruffieux, B. (2004), "Revealing Consumers' Willingness-To-Pay: A Comparison of the BDM Mechanism and the Vickrey Auction", Journal of Economic Psychology, Vol. 25 No. 6, pp. 725-741.

Orcutt, G.H. (1950), "Measurement of Price Elasticities in International Trade", The Review of Economics and Statistics, Vol. 32 No. 2, pp. 117-132.

Oskooeea, M.B. and Niroomand, F. (1998), "Long-Run Price Elasticities and the MarshallLerner Condition Revisited", Economics Letters, Vol. 61 No. 1, pp. 101-109.

Panagariya, A. and Gupta, P. (1998), "Anti-dumping Duty versus Price Negotiations", The World Economy, Vol. 21 No. 8, pp. 1003-1019.

Paulino, A.U.S. (2002), "Trade Liberalisation and Export Performance in Selected Developing Countries", Journal of Development Studies, Vol. 39 No. 1, pp. 140-164.

Phatak, A. (1998), International Management, Concepts and Cases, Southwestern Publishing, Cincinnati, $\mathrm{OH}$.

Polli, R. and Cook, V. (1969), "Validity of the Product Life Cycle", The Journal of Business, Vol. 42 No. 4, pp. 385-400.

Rodriguez, C.A. (1980), “The Role of Trade Flows in Exchange Rate Determination: A Rational Expectations Approach", Journal of Political Economy, Vol. 88 No. 6, pp. 1148-1158. 
Sawyer, M.C. (1981), The Economics of Industries Ad Firms, Croom Helm, London, England.

Shoham, A. (1998), "Export Performance: A Conceptualization and Empirical Assessment", Journal of International Marketing, Vol. 6 No. 3, pp. 59-81.

Simonson, I. and Drolet, A. (2004), “Anchoring Effects on Consumers' Willingness-to-Pay and Willingness-to-Accept", Journal of Consumer Research, Vol. 31 No. 3, pp. 681-690.

Spence, M. (1984), "Cost Reduction, Competition, and Industry Performance", Econometrica, Vol. 52 No. 1, pp. 101-122.

Stockman, A.C. (1980), “A Theory of Exchange Rate Determination”, Journal of Political Economy, Vol. 88 No. 4, pp. 673-698.

Sundaram, A. and Black, S. (1992), "The environment and internal organization of multinational enterprises", Academy of Management Journal, Vol. 17 No. 4, pp. 729-757.

Walters, P.G.P. (1989), “A Framework for Export Pricing Decisions", Journal of Global Marketing, Vol. 2 No. 3, pp. 95-111.

Xing, X., and Tang, F.F. (2004), "Pricing online: The case of consumer", International Journal of Commerce and Management, Vol. 14 No. 3/4, pp. 28-40.

Yntema, T.O. (1928), "The Influence of Dumping on Monopoly Price", Journal of Political Economy, Vol. 36 No. 6, pp. 686-698.

Zaribaf, M. (2008), "Pricing Challenges in Global Marketing: A Model for Export Pricing", International Journal of Management Perspectives, Vol. 2 No. 1, pp. 18-31. 